\title{
HUBUNGAN ANTARA KARAKTERISTIK SOSIAL EKONOMI DENGAN PENGAMBILAN KEPUTUSAN INOVASI SIARAN TELEVISI DIGITAL
}

\author{
Haryati \\ Balai Pengkajian dan Pengembangan Komunikasi dan Informatika Bandung (BPPKI) Bandung \\ Jl.Pajajaran No.88 Bandung-40173, Jawa Barat, telp.022-6017493, Fax.022-6021740, HP. 081320636345 \\ e-mail: haryati@kominfo.go.id \\ Naskah diterima tanggal 10 Oktober 2013, disetujui pada tanggal 14 November 2013
}

\section{THE RELATION BETWEEN SOCIO-ECONOMIC CHARACTERISTICS AND THE INNOVATION DECISION MAKING OF DIGITAL TELEVISION BROADCASTS}

\begin{abstract}
Migration from analog to digital technology, requires a lot of preparation, both from the side of the device, the regulation of the broadcasting industry, and the society. This study refers to the Diffusion of Innovations theory (the theory of Diffusion of Innovation) (Rogers, 1986) that try to explain how an innovation (technology) can be accepted into the community, through a process of decision. The aim of the research is to find out the relationship between socio-economic characteristics of the innovation and decision-making broadcast of digital television. This research uses a quantitative approach with descriptive methods aim to find out the relationship between socio-economic characteristics of the innovation and decision-making broadcast of digital television. The research was carried out in seven counties/cities in West Java Province and Banten Province. The selection of samples is carried out by Multistage Random Cluster Sampling. The number of samples as many as 813 people assigned by Proportional Sampling techniques, with the character category of respondents age 15 years until 64 years. Significance test results with the method at the rate of $5 \%$ Pearson pointed out that, the relationship between innovation decision-making variables with socio-economic characteristics on three aspects, namely, education, income, and spending is weak and insignificant, while on access to information, the value of relationships and significant. This suggests the necessity of strengthening the capacity of absorption of community efforts in the face of digital broadcast television, can be done by fixing the value of any existing components on the operational level. As a priority, is how the effort to improve the economy of society, especially in terms of education, income, and expenditure permonth.
\end{abstract}

Keywords: diffusion of innovations, innovation decision-making, socio-economic characteristics.

\begin{abstract}
Abstrak
Migrasi dari teknologi analog ke teknologi digital, membutuhkan banyak persiapan, baik dari sisi perangkat, regulasi, industri penyiaran, maupun masyarakat. Penelitian ini mengacu kepada Diffusion of Innovations theory (teori Difusi Inovasi) (Rogers, 1986) yang mencoba menjelaskan bagaimana sebuah inovasi (teknologi) dapat diterima ke dalam masyarakat, melalui suatu proses keputusan. Tujuannya adalah tersusunnya gambaran difusi inovasi dalam penerapan sistem siaran televisi digital di masyarakat. Penelitian ini menggunakan pendekatan kuantitatif dengan metode deskriptif bertujuan untuk mengetahui hubungan antara karakteristik sosial ekonomi
\end{abstract}


dengan Pengambilan Keputusan Inovasi terhadap siaran televisi digital. Penelitian dilaksanakan di 7(tujuh) Kabupaten/ Kota di Provinsi Jabar dan Provinsi Banten. Pemilihan sampel dilakukan dengan Multistage Cluster Random Sampling. Jumlah sampel sebanyak 813 orang yang ditetapkan dengan teknik Proportional Sampling, kategori responden usia 15 tahun s/d 64 tahun. Hasil uji signifikansi dengan metode Pearson pada tingkat $\alpha 5 \%$ menunjukkan bahwa, hubungan antara variabel Pengambilan Keputusan Inovasi dengan karakteristik sosial ekonomi pada tiga aspek, yaitu pendidikan, pendapatan, dan pengeluaran adalah lemah dan signifikan, sementara pada akses informasi, nilai hubungan sedang dan signifikan. Hal ini mengisyaratkan akan perlunya upaya penguatan kapasitas absorpsi masyarakat dalam menghadapi siaran televisi digital, dapat dilakukan dengan memperbaiki nilai setiap komponen yang ada pada tataran operasional. Sebagai prioritas, adalah bagaimana upaya untuk meningkatkan kemampuan ekonomi masyarakat khususnya dari sisi pendidikan, penghasilan, dan pengeluaran perbulan.

Kata kunci: difusi inovasi, pengambilan keputusan, karakter sosial ekonomi.

\section{PENDAHULUAN}

Perkembangan yang pesat di bidang Teknologi Informasi dan Komunikasi (TIK) atau Infomation and Communication Technology (ICT), telah melahirkan berbagai inovasi baru di bidang TIK serta berdampak secara signifikan pula terhadap perkembangan di bidang penyiaran. Yaitu dengan mulai diterapkannya teknologi digital dalam teknologi penyiaran menggantikan teknologi analog. Teknologi penyiaran saat ini berkembang ke arah teknologi penyiaran digital yang menggunakan satu kanal frekuensi radio untuk menyalurkan beberapa program siaran. International Telecommunication Union (ITU) atau otoritas telekomunikasi internasional melalui the Geneva 2006 Frequency Plan (GEO6) Agreement telah memberi batas akhir (deadline) agar paling lambat 17 Juni 2015, seluruh lembaga penyiaran beralih ke digital.

Indonesia menjadi negara keenam di Asia Tenggara yang melaksanakan migrasi analog ke digital. Sejak tahun 2007 melalui penetapan standar DVB-T, Indonesia telah melakukan persiapan digitalisasi. Indonesia telah mulai melaksanakan penyelenggaraan televisi digital pada 2012, dengan pertimbangan agar dapat memenuhi target migrasi total ke digital pada 2018.

Dasar pertimbangan penyelenggaraan penyiaran televisi dan radio digital sebagaimana disampaikan Kementerian Komunikasi dan Informatika melalui Siaran
Pers No. 55/DJPT.1/KOMINFO/5/2008, (Ditjen SDPPI, 2008), adalah sebagai berikut: a) Sampai saat ini jumlah pemohon penyelenggaraan penyiaran baik televisi maupun radio di Indonesia telah mencapai sekitar 2000-an perusahaan. Kondisi tersebut tidak sepenuhnya tertampung berdasarkan masterplan frekuensi radio penyelenggaraan telekomunikasi khusus untuk keperluan televisi siaran dan radio siaran; b) Jumlah total izin penyelenggaraan penyiaran yang dikeluarkan oleh sejumlah Pemda sudah meningkat demikian tinggi selama ini. Semakin banyaknya perizinan penyiaran oleh sejumlah Pemda selama ini cenderung menimbulkan pemborosan penggunaan sumber daya frekuensi radio. Sehingga dipandang perlu untuk lebih mengefisienkan penggunaan frekuensi radio yang sumber dayanya semakin terbatas; c) Frekuensi radio pada dasarnya tidak menganut sistem hak milik melainkan hak pakai; d) Tren teknologi ke depan cenderung meninggalkan penyiaran analog menuju era digital; e) Model bisnis penggunaan frekuensi radio untuk lembaga penyiaran harus sepenuhnya ditinjau ulang.

Migrasi televisi analog ke televisi digital, dimungkinkan akan berpengaruh besar terhadap perkembangan teknologi televisi di masa depan. Pada era digitalisasi, terjadi konvergensi antar teknologi penyiaran (broadcasting), teknologi komunikasi (telepon), dan teknologi internet (IT). Ketiga teknologi tersebut menyatu dalam satu media transmisi. Dengan teknologi demikian, akses 
masyarakat untuk memperoleh ataupun menyampaikan informasi semakin mudah dan terbuka.

Migrasi televisi analog ke televisi digital, tidak hanya penting bagi penyedia konten dan infrastruktur penyiaran, tetapi juga bagi masyarakat. Saat ini, terdapat sekitar 40 juta unit televisi yang ditonton lebih dari 200 juta orang di seluruh Indonesia. Teknologi televisi digital dipilih karena punya banyak kelebihan dibandingkan dengan analog. Teknologi ini (Yusuf, 2012) punya ketahanan terhadap efek interferensi, derau, dan fading, serta kemudahannya untuk dilakukan proses perbaikan (recovery) terhadap sinyal yang rusak akibat proses pengiriman/transmisi sinyal. Di samping itu, televisi digital menyajikan gambar dan suara yang jauh lebih stabil dan resolusi lebih tajam ketimbang analog. Hal ini dimungkinkan oleh penggunaan sistem Orthogonal Frequency Division Multiplexing (OFDM) yang tangguh dalam mengatasi efek lintas jamak (multipath). Pada sistem analog, efek lintasan jamak menimbulkan echo yang berakibat munculnya gambar ganda (seakan ada bayangan). Kelebihan lainnya adalah ketahanan terhadap perubahan lingkungan yang terjadi karena pergerakan pesawat penerima (untuk penerimaan mobile), misalnya di kendaraan yang bergerak, sehingga tidak terjadi gambar bergoyang atau berubah-ubah kualitasnya seperti pada televisi analog saat ini.

Di sisi lain, migrasi dari teknologi analog ke teknologi digital, membutuhkan banyak persiapan yang tidak mudah dan tidak murah, baik dari sisi perangkat maupun regulasi, dan industri penyiaran itu sendiri. Migrasi dari teknologi analog ke teknologi digital, membutuhkan penggantian perangkat pemancar televisi dan penerima siaran televisi. Karena pesawat televisi analog tidak bisa menerima sinyal digital, maka diperlukan alat tambahan yang dikenal dengan Set-Top Box yang berfungsi menerima dan mengubah sinyal digital menjadi sinyal analog. Set-Top Box berguna untuk meminimalkan risiko kerugian (baik bagi operator televisi maupun masyarakat) agar pesawat penerima analog dapat menerima siaran analog dari pemancar televisi yang menyiarkan siaran televisi digital, sehingga pemirsa (masyarakat) yang telah memiliki pesawat penerima televisi analog secara perlahan-lahan dapat beralih ke teknologi televisi digital dengan tanpa terputus layanan siaran yang ada selama ini.

Di sisi regulasi pemerintah melalui Kementerian Komunikasi dan Informatika telah menyiapkan sejumlah aturan antara lain, Peraturan Menteri Kominfo No.22/PER/M.KOMINFO/11/2011 tentang Penyelenggaraan Penyiaran Televisi Digital Terestrial Penerimaan Tetap Tidak Berbayar (Free To Air) juga Peraturan Menteri Kominfo No.23/PER/M.KOMINFO/11/2011 tentang Rencana Induk (Masterplan) Frekuensi Radio untuk Keperluan Televisi Siaran Digital Terestrial. Rancangan Keputusan Menteri Kominfo tentang Peluang Usaha Penyelenggaraan Penyiaran Multiplexing pada Penyelenggaraan Penyiaran Televisi Digital Terestrial Penerimaan Tetap Tidak Berbayar (Free To Air) di Zona Layanan 4 (DKI Jakarta dan Banten), 5 (Jawa Barat), 6 (Jawa Tengah dan Yogyakarta), 7 (Jawa Timur) dan 15 (Kepulauan Riau).

Migrasi penyiaran televisi analog ke teknologi penyiaran televisi digital perlu diantisipasi sejak dini dengan studi yang mendalam mengenai banyak hal yang terkait antara lain dengan tingkat adopsi inovasi masyarakat terhadap sistem siaran televisi digital. Penelitian ini mengacu kepada Diffusion of Innovations theory (teori Difusi Inovasi) yang diperkenalkan oleh Rogers (1986). Teori Difusi Inovasi mencoba menjelaskan bagaimana sebuah inovasi (teknologi) dapat diterima ke dalam masyarakat, melalui suatu proses keputusan. Rumusan masalah penelitian ini adalah: "Adakah hubungan antara karakteristik sosial ekonomi dengan Pengambilan Keputusan Inovasi siaran televisi digital?". Adapun identifikasi masalahnya sebagai berikut: 1) Apakah ada hubungan antara pendidikan dengan Pengambilan Keputusan Inovasi?; 2) Apakah ada hubungan antara penghasilan perbulan dengan Pengambilan Keputusan Inovasi ?; 3) Apakah ada hubungan antara pengeluaran perbulan dengan Pengambilan 
Keputusan Inovasi ?; dan 4) Apakah ada hubungan antara akses informasi dengan Pengambilan Keputusan Inovasi ?.

Tujuan yang ingin dicapai dari penelitian ini adalah tersusunnya gambaran Difusi Inovasi dalam penerapan sistem siaran televisi digital di masyarakat. Adapun kegunaan penelitian ini, sebagai bahan masukan bagi Kementerian Komunikasi dan Informatika khususnya Direktorat Penyelenggaraan Pos dan Informatika (PPI) dalam menentukan arah kebijakan terkait penerapan sistem siaran televisi digital di Indonesia. Kegunaan secara praktis adalah sebagai wawasan bagi praktisi dalam pengembangan sistem siaran televisi digital. Sementara kegunaan secara teoretis adalah sebagai pengembangan khasanah akademis terutama dalam mengembangkan sistem siaran televisi digital.

\section{LANDASAN KONSEP}

\section{Kajian Pustaka}

Dalam memberikan khasanah ilmiah tentang prospek sistem penyiaran di era televisi digital, maka dipandang perlu merujuk dan mengkaji hasil penelitian terdahulu yang sejenis, artinya memiliki kesamaan baik konsep, tema, atau metode. Hal ini dimaksudkan untuk memberikan ruang ilmiah yang lebih luas dan dalam mengembangkan arah penelitian.

Kajian pustaka dalam bab ini mengkaji hasil penelitian terdahulu yang dianggap relevan dengan penelitian yang sedang dilakukan, yaitu pertama, penelitian dengan judul "Model Bisnis Penyiaran Televisi Digital di Indonesia" ditulis oleh Arif Wibawa, Subhan Afifi, dan Agung Prabowo, Prodi Ilmu Komunikasi, FISIP UPN "Veteran" Yogyakarta (Wibawa, dkk, 2011) Kedua, Penelitian berjudul "Studi Kesiapan Masyarakat terhadap Penerapan Sistem Penyiaran Televisi Berteknologi Digital di Indonesia", adalah hasil penelitian yang disusun oleh Tim Peneliti Badan Lkitbang SDM Kementerian Kominfo, dengan Tim
Peneliti terdiri dari: Drs. Soemarsono, M.Si; Drs. Aminsar Manihuruk, M.Si; S. Arifianto, SE., MA.; Drs. Heru Pudjo Buntoro, MA; Drs. Heri Kristanto; Drs. Yuli Hartono, M.Si.; Dra. Siti Wahyuningsih, M.Si (Soemarsono, dkk, 2010). Pada tabel 1 menggambarkan perbedaan kedua penelitian tersebut dengan penelitian "Hubungan antara Karakteristik Sosial Ekonomi dengan Pengambilan Keputusan Inovasi Siaran Televisi Digital".

Penelitian ini menjadi penting untuk dilaksanakan, berbeda dengan dua penelitian yang dirujuk, penelitian tersebut tidak melakukan pengambilan variabel adopsi masyarakat terhadap inovasi sistem siaran televisi digital. Aspek tingkat adopsi dipandang penting untuk dikaji, mengingat sistem penyiaran televisi digital merupakan teknologi penyiaran yang memiliki karakteristik yang berbeda dengan sistem penyiaran analog yang selama ini dinikmati masyarakat Indonesia.

\section{Kerangka Pemikiran}

Migrasi Sistem Analog ke Sistem Digital

Televisi digital atau penyiaran digital (Sindonews.com, 2013) adalah jenis televisi yang menggunakan modulasi digital dan sistem kompresi untuk menyiarkan sinyal video, audio, dan data ke pesawat televisi. Stasiun televisi memanfaatkan sistem teknologi digital (khususnya perangkat studio) untuk memproduksi program, editing, recording, dan menyimpan data. Pengiriman sinyal gambar, suara, dan data menggunakan sistem transmisi digital dengan menggunakan satelit hanya dimanfaatkan oleh siaran televisi berlangganan.

Aplikasi teknologi digital pada sistem penyiaran televisi yang dikembangkan di pertengahan tahun 90-an dan diujicobakan pada tahun 2000. Pada awal pengoperasian sistem digital, dilakukan siaran televisi secara bersama dengan siaran analog sebagai masa transisi. Ujicoba sistem tersebut dilakukan sampai mendapatkan hasil penerapan siaran televisi digital yang paling ekonomis, sesuai dengan kebutuhan dari negara yang mengoperasikan (Subarkah, 2009). 
Tabel 1

\section{Perbedaan Penelitian tentang "Hubungan antara Karakteristik Sosial Ekonomi dengan Pengambilan Keputusan Inovasi Siaran Televisi Digital” dengan Penelitian Terdahulu}

\begin{tabular}{|c|c|c|c|}
\hline \multirow[b]{2}{*}{$\begin{array}{l}\text { Deskripsi } \\
\text { penelitian }\end{array}$} & \multicolumn{3}{|c|}{ Judul Penelitian } \\
\hline & $\begin{array}{l}\text { Model Bisnis Penyiaran } \\
\text { Televisi Digital di Indonesia }\end{array}$ & $\begin{array}{c}\text { Studi Kesiapan } \\
\text { Masyarakat terhadap } \\
\text { Penerapan Sistem } \\
\text { Penyiaran Televisi } \\
\text { Berteknologi Digital di } \\
\text { Indonesia }\end{array}$ & $\begin{array}{c}\text { Hubungan antara } \\
\text { Karakteristik Sosial } \\
\text { Ekonomi dengan } \\
\text { Pengambilan Keputusan } \\
\text { Inovasi Siaran Televisi } \\
\text { Digital.* }\end{array}$ \\
\hline $\begin{array}{l}\text { Pendekatan } \\
\text { Penelitian }\end{array}$ & Pendekatan socio-technical & Pendekatan Kualitatif & Pendekatan kuantitatif \\
\hline Tujuan Penelitian & $\begin{array}{l}\text { mencermati model bisnis } \\
\text { penyiaran televisi digital, } \\
\text { yaitu melihat interrelasi } \\
\text { antara ketiga subsistem } \\
\text { sekaligus yaitu subsistem } \\
\text { teknologi, subsistem sosial } \\
\text { dan subsistem lingkungan }\end{array}$ & $\begin{array}{l}\text { memberikan gambaran } \\
\text { secara mendalam tentang } \\
\text { kesiapan masyarakat } \\
\text { menyongsong } \\
\text { diterapkannya sistem } \\
\text { penyiaran televisi digital } \\
\text { secara nasional. }\end{array}$ & $\begin{array}{c}\text { melihat hubungan antara } \\
\text { dua variabel karakteristik } \\
\text { sosial ekonomi masyarakat } \\
\text { dengan Pengambilan } \\
\text { Keputusan Inovasi Siaran } \\
\text { Televisi Digital. }\end{array}$ \\
\hline $\begin{array}{c}\text { Teknik } \\
\text { Pengumpulan } \\
\text { Data }\end{array}$ & $\begin{array}{l}\text { Teknik konsultasi, focus } \\
\text { group discussion, kuesioner, } \\
\text { dan studi kebijakan. }\end{array}$ & $\begin{array}{l}\text { Wawancara mendalam } \\
\text { terhadap informan kunci } \\
\text { yang terdiri dari pengamat } \\
\text { atau praktisi teknologi } \\
\text { informasi; budayawan } \\
\text { ekonom; praktisi } \\
\text { penyiaran; pendidik tokoh } \\
\text { masyarakat; pemilik } \\
\text { rumah produksi. }\end{array}$ & $\begin{array}{c}\text { Teknik survei. Sampel } \\
\text { penelitian, adalah } \\
\text { masyarakat dengan rentang } \\
\text { usia } 15 \mathrm{~s} / \mathrm{d} 60 \text { tahun. Lokasi } \\
\text { penelitian di lima } \\
\text { Kabupaten/ kota di } \\
\text { ProvinsiJabar dan Banten. }\end{array}$ \\
\hline Fokus Penelitian & $\begin{array}{l}\text { Model bisnis penyiaran } \\
\text { televisi }\end{array}$ & $\begin{array}{l}\text { Kesiapan masyarakat } \\
\text { terhadap penerapan sistem } \\
\text { penyiaran televisi digital }\end{array}$ & $\begin{array}{l}\text { Tingkat adopsi inovasi } \\
\text { terhadap sistem siaran } \\
\text { televisi digital }\end{array}$ \\
\hline
\end{tabular}

Keterangan: * Penelitian yang dilaksanakan

Televisi digital atau penyiaran digital adalah jenis televisi yang menggunakan modulasi digital dan sistem kompresi untuk menyiarkan sinyal video, audio, dan data ke pesawat televisi.

Pengembangan televisi digital antara lain karena dua faktor, pertama, perubahan lingkungan eksternal, yang meliputi pasar televisi analog yang sudah jenuh; Kompetisi dengan sistem penyiaran satelit dan kabel; dan perkembangan teknologi. Kedua, teknologi pemrosesan sinyal digital, meliputi, teknologi transmisi digital, teknologi semikonduktor, dan teknologi peralatan yang beresolusi tinggi.

Terdapat empat standar besar yang menjadi arah standar dalam dunia broadcasting yakni; (Kominfo, 2012): DVB yang dianut oleh negara-negara Eropa; Standar ATSC yang dianut oleh USA; standar ISDB yang merupakan standar siaran televisi digital yang berasal dari Jepang dan diadopsi oleh Brazil, serta standar DMB dari Korea Selatan. Saat ini hampir 50\% lebih negara- 
negara di dunia mulai beralih atau mulai mengkaji peralihan sistem penyiaran di negaranya menuju penyiaran digital.

Pada tanggal 27 Maret 2007, Menkominfo menerbitkan Peraturan Menteri No. 07/P/M.KOMINFO/3/2007 tentang Standar Penyiaran Digital Terestrial untuk Televisi Tidak Bergerak. Keputusan itu menetapkan standar DVB-T sebagai standar penyiaran televisi digital terestrial tidak bergerak di Indonesia. Pemerintah telah memutuskan sistem Digital Video Broadcasting-Terrestrial (DVB-T) sebagai standar nasional Indonesia karena dari hasil ujicoba yang dilakukan oleh Tim Nasional Migrasi televisi dan Radio dari analog ke digital, teknologi DVB-T lebih unggul dan memiliki manfaat lebih dibandingkan dengan teknologi penyiaran digital lainnya.

Teknologi ini (Subiantoro, 2010) mampu memultipleks beberapa program sekaligus, di mana enam program siaran dapat "dimasukkan" ke dalam satu kanal televisi berlebar pita $8 \mathrm{MHz}$, dengan kualitas jauh lebih baik. Ibarat satu lahan, yang semula hanya dapat dimanfaatkan untuk satu rumah, dengan teknologi ini mampu dibangun enam rumah dengan kualitas bangunan jauh lebih baik dan kapasitas ruangan lebih banyak. Di samping itu, penambahan varian DVB-H (handheld) mampu menyediakan tambahan sampai enam program siaran lagi untuk penerimaan bergerak (mobile). Hal ini sangat memungkinkan bagi penambahan siaransiaran televisi baru.

Siaran DVB-T pun diklaim mempunyai banyak keunggulan dibandingkan dengan siaran televisi analog. Teknologi ini punya ketahanan terhadap efek interferensi, derau, dan fading, serta kemudahannya untuk dilakukan proses perbaikan (recovery) terhadap sinyal yang rusak akibat proses pengiriman/transmisi sinyal. Perbaikan akan dilakukan di bagian penerima dengan suatu kode koreksi error (error correction code) tertentu. Kelebihan lainnya adalah efisiensi di banyak hal, antara lain pada spektrum frekuensi (efisiensi bandwidth), efisiensi dalam network transmission, transmission power, maupun consumption power.

Di samping itu, televisi digital menyajikan gambar dan suara yang jauh lebih stabil dan resolusi lebih tajam ketimbang analog. Hal ini dimungkinkan oleh penggunaan sistem Orthogonal Frequency Division Multiplexing (OFDM) yang tangguh dalam mengatasi efek lintas jamak (multipath). Pada sistem analog, efek lintasan jamak menimbulkan echo yang berakibat munculnya gambar ganda (seakan ada bayangan).

Kelebihan lainnya adalah ketahanan terhadap perubahan lingkungan yang terjadi karena pergerakan pesawat penerima (untuk penerimaan mobile), misalnya di kendaraan yang bergerak, sehingga tidak terjadi gambar bergoyang atau berubah-ubah kualitasnya seperti pada televisi analog saat ini.

Keputusan pemerintah dengan menetapkan DVB-T sebagai standar televisi digital terestrial diharapkan dapat mendorong pelaksanaan migrasi dari era penyiaran analog menuju era penyiaran digital di Indonesia. Keputusan pemerintah ini tidak saja migrasi analog ke digital ini membuka peluang ketersediaan saluran siaran yang lebih banyak, namun juga dapat berimplikasi dalam banyak aspek, terutama dalam memicu tumbuh dan berkembangnya kemandirian bangsa.

\section{Teori Difusi Inovasi}

Teori Difusi Inovasi diperkenalkan oleh tokoh-tokoh seperti Everett M. Rogers dengan karya besarnya Diffusion of Innovation (1961); F. Floyd Shoemaker yang bersama Rogers menulis Communication of Innovation: A Cross Cultural Approach (1971) sampai Lawrence A. Brown yang menulis Innovation Diffusion: $A$ New Perpective (1981).

Teori ini mengasumsikan bahwa media dan hubungan interpersonal memberikan informasi sekaligus memengaruhi opini dan penilaian seseorang terhadap inovasi tertentu. Informasi mengalir melalui jaringan dan opinion leaders yang kemudian berperan dalam menentukan tingkat penerimaaan seseorang terhadap sebuah inovasi.

Rogers (1995) mendefinisikan difusi sebagai proses di mana suatu inovasi 
dikomunikasikan melalui saluran tertentu dalam jangka waktu tertentu di antara para anggota suatu sistem sosial (the process by which an innovation is communicated through certain channels overtime among the members of a social system). Di samping itu, difusi juga dapat dianggap sebagai suatu jenis perubahan sosial yaitu suatu proses perubahan yang terjadi dalam struktur dan fungsi sistem sosial.

Inovasi adalah "an idea, practice, or object perceived as new by the individual." (suatu gagasan, praktik, atau benda yang dianggap/dirasa baru oleh individu). Ungkapan dianggap/dirasa baru terhadap suatu ide, praktik, atau benda oleh sebagian orang, belum tentu juga pada sebagian yang lain. Kesemuanya tergantung apa yang dirasakan oleh individu atau kelompok terhadap ide, praktik, atau benda tersebut.

Dari definisi di atas, maka difusi inovasi adalah suatu proses penyebarserapan ide-ide atau hal-hal yang baru dalam upaya untuk mengubah suatu masyarakat yang terjadi secara terus menerus dari suatu tempat ke tempat yang lain, dari suatu kurun waktu ke kurun waktu yang berikut, dari suatu bidang tertentu ke bidang yang lainnya kepada sekelompok anggota dari sistem sosial.

Tujuan utama dari difusi inovasi adalah diadopsinya suatu inovasi (ilmu pengetahuan, teknologi, bidang pengembangan masyarakat) oleh anggota sistem sosial tertentu. Sistem sosial dapat berupa individu, kelompok informal, organisasi sampai kepada masyarakat (Hafni, 2011).

Proses keputusan inovasi memiliki lima tahap, yaitu: knowledge (pengetahuan), persuasion (kepercayaan), decision (keputusan), implementation (penerapan), dan confirmation (konfirmasi), dengan masingmasing deskripsi sebagai berikut ini (Rogers, 1995).

1. Pengetahuan (Knowledge)

Proses keputusan inovasi ini dimulai dengan Knowledge Stage. Pada tahapan ini suatu individu belajar tentang keberadaan suatu inovasi dan mencari informasi tentang inovasi tersebut. Menurut Rogers, tahapan ini akan membentuk tiga jenis pengetahuan (knowledge): (a) Awareness-knowledge; Merupakan pengetahuan akan keberadaan suatu inovasi. (b) How-to-knowledge. Yaitu pengetahuan tentang bagaimana cara menggunakan suatu inovasi dengan benar. (c) Principles-knowledge. Yakni pengetahuan tentang prinsip-prinsip keberfungsian yang mendasari bagaimana dan mengapa suatu inovasi dapat bekerja.

2. Tahap Persuasi (Persuasion Stage)

Tahap kedua ini terjadi lebih banyak dalam tingkat pemikiran calon pengguna. Inovasi yang dimaksud berkaitan dengan karakteristik inovasi itu sendiri, (Severin dan Tankard, 2005). 1) Keunggulan relatif (relative advantage). Keunggulan relatif adalah derajat di mana suatu inovasi dianggap lebih baik/unggul dari yang pernah ada sebelumnya. 2) Kompatibilitas (compatibility). Kompatibilitas adalah derajat di mana inovasi tersebut dianggap konsisten dengan nilai-nilai yang berlaku, pengalaman masa lalu dan kebutuhan pengadopsi. 3) Kerumitan (complexity). Kerumitan adalah derajat di mana inovasi dianggap sebagai suatu yang sulit untuk dipahami dan digunakan. 4) Kemampuan diujicobakan (trialability). Kemampuan untuk diujicobakan adalah derajat di mana suatu inovasi dapat diujicoba batas tertentu. 5) Kemampuan diamati (observability). Kemampuan untuk diamati adalah derajat di mana hasil suatu inovasi dapat terlihat oleh orang lain. Semakin mudah seseorang melihat hasil dari suatu inovasi, semakin besar kemungkinan orang atau sekelompok orang tersebut mengadopsi.

3. Tahap Keputusan (Decision Stage)

Pada tahapan ini individu membuat keputusan apakah menerima atau menolak suatu inovasi.

4. Tahap Implementasi (Implementation Stage)

Pada tahap implementasi, sebuah inovasi dicoba untuk dipraktikkan, akan tetapi sebuah inovasi membawa sesuatu yang baru apabila tingkat ketidakpastiannya akan terlibat dalam difusi. 
5. Tahap Konfirmasi (Confirmation Stage) Ketika keputusan inovasi sudah dibuat, pengguna akan mencari dukungan atas keputusannya.

\section{METODE PENELITIAN}

Metode penelitian yang digunakan adalah deskriptif. Deskriptif yaitu penelitian yang memusatkan perhatian pada pemecahan masalah yang ada pada masa sekarang dan bertitik tolak dari data yang dikumpulkan, dianalisis dan disimpulkan dalam konteks teori-teori dari hasil penelitian terdahulu (Surakhmad, 1994). Teknik pengumpulan data penelitian yang digunakan adalah teknik survei.

Dalam penelitian ini teknologi siaran televisi digital dipandang sebagai bentuk inovasi baru. Tingkat adopsi inovasi adalah penerimaan terhadap inovasi sistem siaran televisi digital. Menurut, Rogers (1995), karakteristik unit pengambilan keputusan menjadi variabel yang memengaruhi adopsi inovasi. Penerimaan terhadap suatu inovasi oleh suatu masyarakat tidaklah terjadi secara serempak tetapi berbeda-beda sesuai dengan pengetahuannya dan kesiapan menerima halhal tersebut. Rogers dan Shoemaker (1971) memperkenalkan sebuah formula baru dalam proses adopsi inovasi. Teori adopsi tersebut diformulasikan menjadi empat tahap yaitu: 1) Pengetahuan; 2) Persuasi; 3) Keputusan; 4) Implementasi; 5) Konfirmasi.

Sistem siaran televisi digital di Indonesia, saat ini belum secara menyeluruh diterapkan di masyarakat. Karena itu dalam penelitian ini untuk variabel Pengambilan Keputusan Inovasi, indikator yang diteliti dibatasi pada tiga tahap saja, yaitu: tahap pengetahuan, tahap persuasi, dan tahap keputusan.

Karakteristik sosial ekonomi merupakan tanda atau ciri-ciri dari seseorang yang ada di dalam dan di luar pribadi seseorang yang diduga dapat memengaruhi adopsi, termasuk adopsi terhadap teknologi sistem siaran televisi digital. Variabel karakteristik sosial ekonomi dilihat dari aspek-aspek pendidikan, pendapatan setiap bulan, dan pengeluaran setiap bulan, serta akses informasi. Karakteristik sosial ekonomi meliputi pendidikan formal, tingkat penghasilan dan pengeluaran dan akses informasi.

Dengan demikian variabel yang akan digunakan dalam penelitian ini adalah: Variabel Bebas (X): Karakteristik sosial ekonomi dan Variabel Terikat (Y): Pengambilan Keputusan Inovasi siaran televisi digital.

\section{Hipotesis}

Hipotesis dalam penelitian ini adalah:

Ho: Tidak ada hubungan antara karakteristik sosial ekonomi dengan Pengambilan Keputusan Inovasi siaran televisi digital Hi: Ada hubungan antara karakteristik sosial ekonomi dengan Pengambilan Keputusan Inovasi siaran televisi digital.

Dalam penelitian ini populasi adalah masyarakat di 5 (lima) kota/ Kabupaten yang berada di wilayah Provinsi Jabar, dan 2 (dua) kota di Provinsi Banten, dengan rentang usia produktif 15 tahun s/d 64 tahun. Lokasi dipilih secara acak dari kota/ Kabupaten di dua provinsi tersebut, masing-masing 5 kota/Kabupaten di Provinsi Jabar dan dan 2 kota di Provinsi Banten. Pemilihan sampel dilakukan dengan Multistage Cluster Random Sampling (sampling dengan gugus banyak tahap). Penentuan sampel dilakukan dengan teknik Proportional Sampling, dengan proporsi $20 \%$ dari jumlah penduduk setiap kota/ Kabupaten terpilih dengan kategori responden berada pada usia produktif 15 tahun s/d 64 tahun. Sehingga diperoleh jumlah sampel secara total 813 orang.

Teknik pengumpulan datanya berdasar pada: (1) Kajian Pustaka; (2) Kuesioner. Dalam menguji hipotesis, yaitu hubungan antara variabel-variabel karakteristik sosial ekonomi dan Pengambilan Keputusan Inovasi siaran televisi digital, digunakan Uji Koefisien Korelasi Product Moment hasil kali Pearson. 


\section{HASIL PENELITIAN DAN PEMBAHASAN}

\section{Hasil Penelitian \\ Identitas Responden}

Jumlah responden dalam penelitian ini berjumlah 813 orang. Berdasarkan kuesioner, jumlah responden menurut jenis kelamin terdiri dari 443 orang laki-laki $(54,49 \%)$ dan 370 orang perempuan $(45,51 \%)$. Sementara berdasarkan kelompok usia, terdiri dari 245 orang $(30,14 \%)$ berada pada kelompok usia 26-35 tahun; 219 orang (26,94\%) kelompok usia $15-25$ tahun; 177 orang $(21,77 \%)$ pada kelompok usia 36-45 tahun; 132 orang $(16,24 \%)$ pada kelompok usia 45-55 tahun; dan 40 orang $(4,92 \%)$ pada kelompok usia 56-60 tahun. Berdasarkan status marital, sebagian besar responden atau 513 orang $(63,10 \%)$ berstatus menikah; 278 orang $(34,19 \%)$ belum menikah, dan 22 orang $(2,71 \%)$ janda/ duda. Dalam bidang matapencaharian, 213 orang $(26,20 \%)$ adalah pegawai swasta; 141 orang $(17,34 \%)$ PNS; 134 orang $(16,48 \%)$ wiraswasta; 99 orang (mahasiswa; 47 orang $(5,78 \%)$ pelajar; 21 orang $(2,58 \%)$ pensiunan ABRI/ PNS; dan tidak bekerja dan ibu rumah tangga 143 orang $(17,59 \%)$. Acara atau siaran televisi nasional maupun daerah yang paling sering ditonton responden tertinggi adalah RCTI (162 orang atau $20,10 \%$ ) disusul oleh Trans TV 150 orang (18,61\%), Trans 7122 orang $(15,14 \%)$, TV One 119 orang $(14,76 \%)$.

\section{Karakteristik Sosial Ekonomi}

Variabel karakteristik sosial ekonomi dilihat dari aspek-aspek pendidikan, pendapatan setiap bulan, dan pengeluaran setiap bulan, serta akses informasi, berdasarkan hasil penelitian dapat digambarkan pada gambar 1 .

Berdasarkan gambaran data tersebut, setelah dikelompokkan dalam tiga kategori tinggi, sedang, rendah, karakteristik sosial ekonomi responden, menunjukkan, sebanyak 616 orang $(75,77 \%)$ berada pada kategori sedang, 183 orang $(22,51 \%)$ kategori rendah, dan 14 orang $(1,72 \%)$ pada kategori tinggi, lebih jelas dapat digambarkan pada gambar 2 .
Karakteristik sosial ekonomi

Tingkat pendidikan

Tingkat penghasilan

Tingkat pengeluaran

Akses Informasi

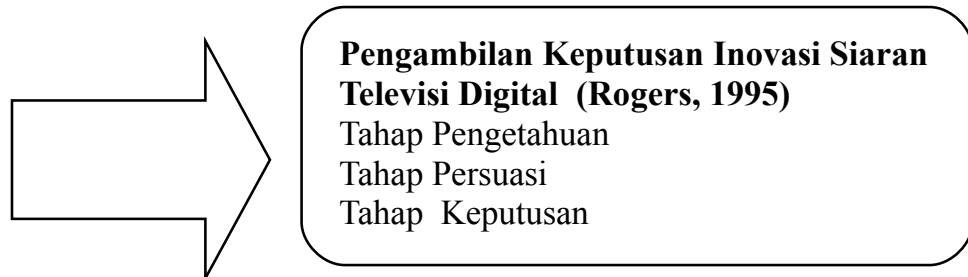

Gambar 1

Variabel Penelitian

Tabel 2

Distribusi Responden Berdasarkan Karakteristik Sosial Ekonomi

\begin{tabular}{clcccccc}
\hline \multirow{2}{*}{ No. } & \multicolumn{1}{c}{ Item } & \multicolumn{2}{c}{ Kategori Rendah } & \multicolumn{2}{c}{ Kategori Sedang } & \multicolumn{2}{c}{ Kategori Tinggi } \\
\cline { 3 - 8 } & & $\mathbf{f}$ & $\mathbf{\%}$ & $\mathbf{f}$ & $\mathbf{\%}$ & $\mathbf{f}$ & $\mathbf{\%}$ \\
\hline 1. & Tingkat Pendidikan & 106 & $13.04 \%$ & 501 & $61.62 \%$ & 206 & $25.34 \%$ \\
2. & $\begin{array}{l}\text { Penghasilan per bulan } \\
\text { 3. }\end{array}$ & 193 & $23.74 \%$ & 569 & $69.99 \%$ & 51 & $6.27 \%$ \\
pengeluaran untuk kebutuhan hidup setiap & 226 & $27.80 \%$ & 538 & $66.17 \%$ & 49 & $6.03 \%$ \\
4. & Akses Informasi & 190 & $23.37 \%$ & 498 & $61.25 \%$ & 125 & $15.38 \%$ \\
\hline
\end{tabular}

Sumber : Analisis Data Primer 


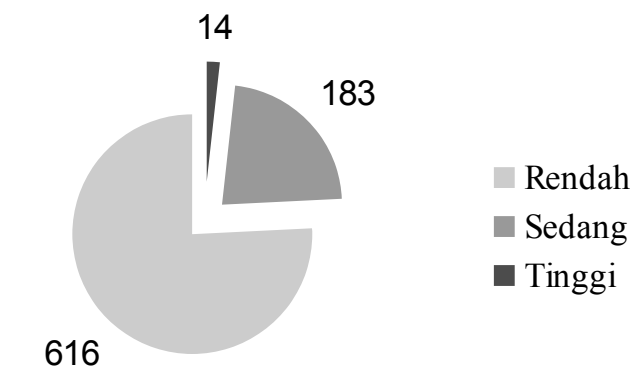

Sumber : Analisis Data Primer

Gambar 2

\section{Karakteristik Sosial Ekonomi}

Pengambilan Keputusan Inovasi Siaran Televisi Digital

Pengambilan Keputusan Inovasi Siaran Televisi Digital, dilihat dari tahap pengetahuan, tahap persuasi, dan tahap keputusan, berdasarkan hasil penelitian dapat digambarkan sebagai beikut:

Knowledge Stage. Tahap Pengetahuan responden mengenai sistem siaran televisi digital, terdiri dari aspek-aspek pengetahuan yaitu, Awareness-knowledge, How-toknowledge, dan Principles-knowledge, berdasarkan 3 (tiga) kategori, tinggi, sedang, dan rendah dapat dilihat pada tabel 3.

Awareness-knowledge; Merupakan pengetahuan akan keberadaan suatu inovasi. Pengetahuan jenis ini akan memotivasi individu untuk belajar lebih banyak tentang inovasi dan kemudian akan mengadopsinya. Ternyata pengetahuan akan keberadaan sistem siaran televisi digital berada pada kategori rendah $(77,74 \%)$. Sebanyak 20\% lebih responden berada pada kategori sedang dan tinggi, artinya yang telah mengetahui program migrasi siaran televisi analog ke televisi digital, sumber informasinya sebagian besar adalah dari televisi dan internet. Begitu pula dengan How-to-knowledge, yaitu pengetahuan tentang bagaimana cara menggunakan suatu inovasi dengan benar serta Principles-knowledge, yakni pengetahuan tentang prinsip-prinsip keberfungsian yang mendasari bagaimana dan mengapa suatu inovasi dapat bekerja, dua aspek ini sebagian besar berada pada kategori rendah.

Tabel 3

Distribusi Responden Berdasarkan Tahap Pengetahuan

\begin{tabular}{cccccccc}
\hline \multirow{2}{*}{ No. } & Item & \multicolumn{2}{c}{ Kategori Rendah } & \multicolumn{2}{c}{ Kategori Sedang } & \multicolumn{2}{c}{ Kategori Tinggi } \\
\cline { 3 - 8 } & & $\mathbf{f}$ & $\mathbf{\%}$ & $\mathbf{f}$ & $\mathbf{\%}$ & $\mathbf{f}$ & $\mathbf{\%}$ \\
\hline 1. & Awareness-knowledge & 632 & $77.74 \%$ & 180 & $22.14 \%$ & 1 & $0.12 \%$ \\
2. & How-to-knowledge & 738 & $90.77 \%$ & 74 & $9.10 \%$ & 1 & $0.12 \%$ \\
3. & Principles-knowledge & 528 & $64.94 \%$ & 271 & $33.33 \%$ & 14 & $1.72 \%$ \\
\hline
\end{tabular}

Sumber : Analisis Data Primer 


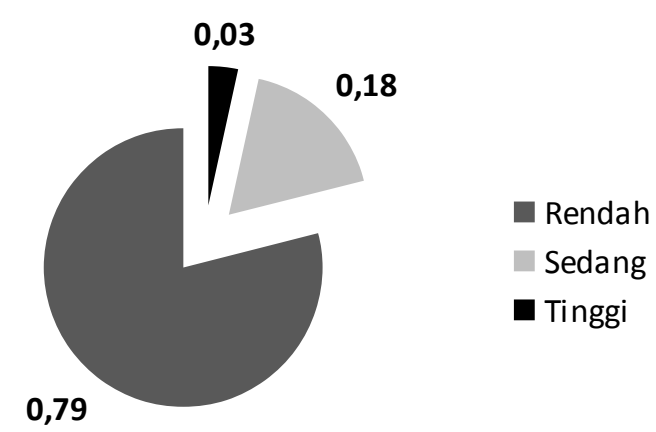

Sumber : Analisis Data Primer

Gambar 3

Tahap Pengetahuan

Berdasarkan data tersebut, tahap pengetahuan responden digambarkan pada gambar 3. Tahap pengetahuan responden terhadap sistem siaran televisi digital berada pada proporsi kategori rendah $(78,97 \%)$. Meskipun demikian, responden sebagian besar menyambut baik terhadap kehadiran sistem siaran televisi digital ini. Komposisi ini bisa menjelaskan, bahwa program migrasi ke televisi digital itu belum ada gaungnya di masyarakat. Berarti bahwa frekuensi sosialisasi yang dilakukan oleh pemerintah belum banyak. Dapat terjadi karena kurangnya/belum adanya program sosialisasi tentang program tersebut. Sebagai solusi rekomendasinya adalah perlu dibuat dan dilaksanakannya program sosialisasi untuk mencegah kemungkinan-kemungkinan terjadinya resistensi massal.

Persuasion Stage. Rogers (1995) memberikan beberapa hal yang memengaruhi cepat atau lambatnya suatu inovasi diadopsi oleh individu atau masyarakat adopters yaitu: a. Relative advantage (keunggulan relatif); $b$. Compatibility (kesesuaian), c. Complexity (kerumitan), d. Trialability (ketercobaan), e. Observability (keteramatan). Hasil-hasil penelitian (dalam Rogers, 1995) menunjukkan adanya hubungan positif aspek-aspek inovasi dengan kecepatan adopsinya. Hasil tersebut menunjukkan bahwa 49\% - 87\% varian dalam kecepatan adopsi dijelaskan oleh lima aspek (keunggulan relatif, kesesuaian, kerumitan, ketercobaan, dan keteramatan). Pada tabel 4 memperlihatkan, sebagian besar aspek tahap persuasi memiliki persentase yang relatif sedang-tinggi. Berdasarkan data tersebut, tahap persuasi responden digambarkan pada gambar 4.

Tabel 4

Distribusi Responden Berdasarkan Tahap Persuasi

\begin{tabular}{llcccccc}
\hline \multirow{2}{*}{ No. } & \multicolumn{1}{c}{ Item } & \multicolumn{2}{c}{ Kategori Rendah } & \multicolumn{2}{c}{ Kategori Sedang } & \multicolumn{2}{c}{ Kategori Tinggi } \\
\cline { 3 - 8 } & & $\mathbf{f}$ & $\mathbf{\%}$ & $\mathbf{f}$ & $\mathbf{\%}$ & $\mathbf{f}$ & $\%$ \\
\hline 1. & Keunggulan Relatif & 21 & $2.58 \%$ & 484 & $59.53 \%$ & 308 & $37.88 \%$ \\
2. & Kenyamanan \& Kepuasan & 18 & $2.21 \%$ & 122 & $15.01 \%$ & 673 & $82.78 \%$ \\
3. & Kompatibilitas & 22 & $2.71 \%$ & 110 & $13.53 \%$ & 681 & $83.76 \%$ \\
4. & Kerumitan & 73 & $8.98 \%$ & 220 & $27.06 \%$ & 520 & $63.96 \%$ \\
5. & Kemampuan diujicobakan & 64 & $7.87 \%$ & 643 & $79.09 \%$ & 106 & $13.04 \%$ \\
6. & Kemampuan diamati & 51 & $6.27 \%$ & 461 & $56.70 \%$ & 301 & $37.02 \%$ \\
\hline
\end{tabular}

Sumber : Analisis Data Primer 


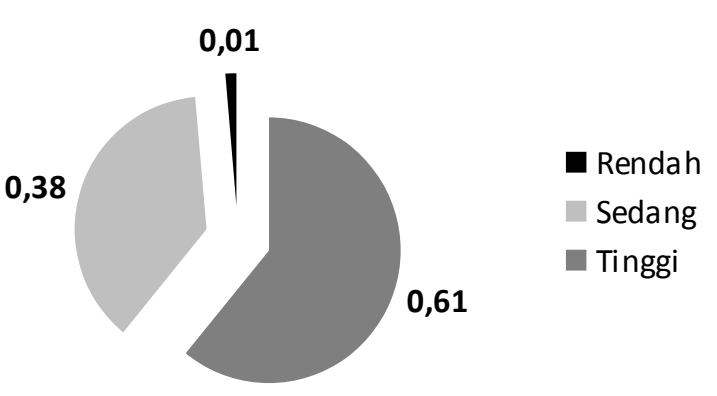

Sumber : Analisis Data Primer

Gambar 4

Tahap Persuasi

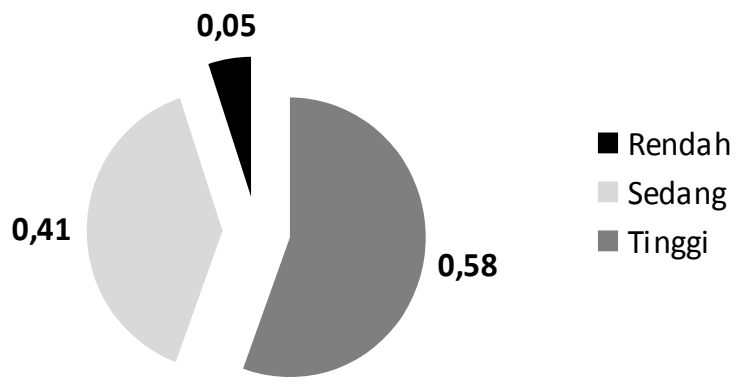

Sumber : Analisis Data Primer

\section{Gambar 5}

Tahap Keputusan

Tahap keputusan, ternyata hasil pengategorian menyebar ke dalam tiga kategori rendah, sedang, dan tinggi, yang mayoritas responden masuk ke dalam kategori tinggi yaitu sekitar $57,93 \%$ dan kategori tinggi 40,96\%.

Responden pada umumnya merasa senang sekali terhadap kehadiran program penyiaran televisi digital, dan sebagian kecil saja yang menyatakan biasa saja. Sebaliknya yang merasa tidak senang juga cukup besar, umumnya mereka tidak siap secara ekonomi. Komposisi ini memperlihatkan ekspektasi yang tinggi terhadap adanya program migrasi ke televisi digital. Tingkat ketertarikan ini dapat dipengaruhi oleh informasi yang memberikan gambaran baik terhadap prospek penyiaran televisi digital di masa datang, masyarakat merasa tidak terlalu terbebani untuk merealisasi harapan itu. Respon masyarakat ketika penyiaran televisi digital diberlakukan, menunjukkan, sebagian besar ingin memasang peralatan tambahan/Set-Top Box (STB) dan sebagian yang lain tidak ada kesanggupan. Sementara yang memiliki respon yang sangat reaksioner, yaitu ingin membeli langsung pesawat televisi baru (pesawat digital). Komposisi ini menunjukkan bahwa keberadaan STB dapat disebut sebagai peluang yang baik bagi program migrasi ke televisi digital. Kesediaan masyarakat untuk dengan mudah 'menerima' program migrasi televisi digital ini sangat dipengaruhi oleh keterjangkauannya terhadap harga STB.

Setelah dikumulatifkan berdasarkan aspek-aspek tahap pengetahuan, tahap persuasi, dan tahap keputusan, dapat digambarkan Pengambilan Keputusan Inovasi terhadap sistem siaran televisi digital dalam tiga kategori, memperlihatkan proporsi Pengambilan Keputusan Inovasi terhadap sistem siaran televisi digital berada pada kecenderungan sedang-tinggi, seperti terlihat pada gambar 6 . 


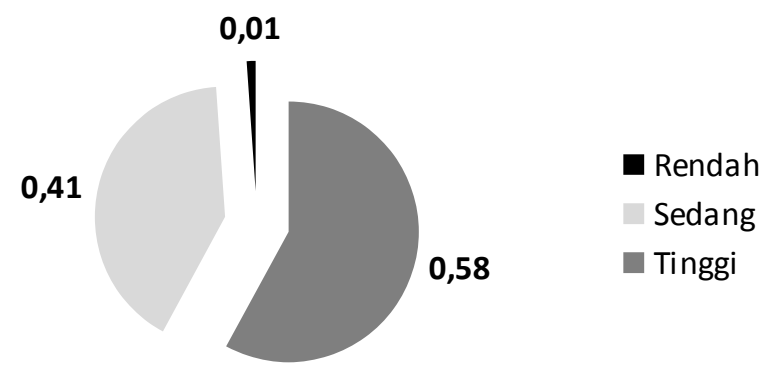

Sumber : Analisis Data Primer

Gambar 6

\section{Pengambilan Keputusan Inovasi Siaran Televisi Digital}

Hubungan antara Karakteristik Sosial Ekonomi dengan Pengambilan Keputusan Inovasi Siaran Televisi Digital

Hasil uji signifikansi dengan metode Pearson pada tingkat $\alpha 5 \%$ menunjukkan bahwa:

1. Tingkat korelasi (hubungan) antara pendidikan dengan Pengambilan Keputusan Inovasi adalah lemah dan signifikan dengan nilai uji 0,398 signifikan pada alpha $0.05(5 \%)$.

2. Tingkat korelasi (hubungan) antara penghasilan perbulan dengan Pengambilan Keputusan Inovasi adalah lemah dan signifikan dengan nilai uji 0,342 signifikan pada alpha $0.05(5 \%)$. Tingkat korelasi (hubungan) antara pengeluaran perbulan dengan Pengambilan Keputusan Inovasi adalah sangat lemah dan tidak signifikan dengan nilai uji 0,262 tetapi masih signifikan pada alpha $0.1(10 \%)$.

3. Tingkat korelasi (hubungan) antara akses informasi dengan Pengambilan Keputusan Inovasi adalah sedang/cukup dan signifikan dengan nilai uji 0,509 signifikan pada alpha $0.05(5 \%)$

\section{Pembahasan}

Penemuan adalah tingkat di mana sebuah inovasi diganti atau dimodifikasi oleh pengguna dalam proses adopsi dan implementasinya (Rogers, 1986). Menurut Rogers dan Shoemaker (1971), adopsi merupakan proses mental dalam pengambilan keputusan untuk menerima atau menolak ide baru dan menegaskan lebih lanjut tentang penerimaan atau penolakan ide tersebut. Proses adopsi terhadap sebuah inovasi teknologi adalah suatu proses perilaku di mana pengadopsi mengubah inovasi tersebut untuk disesuaikan dengan kondisinya. Fakta memperlihatkan, bahwa adopsi teknologi baru jarang dengan gampang diadopsi. Seorang individu harus menjadi sangat terlibat dengan inovasi. Dalam sebuah penelitian di California tentang difusi komputer rumah, pengadopsi secara tipikal melewati periode frustasi dalam beberapa minggu mengatasi masalah dan mencari informasi setelah pertama kali membeli. Mereka secara perlahan-lahan belajar bagaimana menggunakan komputer mereka secara tepat, dan mengaplikasikannya dalam berbagai tugas, seperti mengetik, menghitung, main video game, dan lain-lain. Pada akhirnya, responden penelitian komputer rumah di California menjadi pengadopsi yang puas, dan secara antusias merekomendasikan inovasi tersebut kepada teman mereka. Beberapa dari pengadopsi menjadi sangat tergantung untuk menggunakan komputer mereka.

Salah satu karakteristik yang dipandang cukup relevan dalam melihat tingkat adopsi masyarakat terhadap teknologi komunikasi baru, adalah karakteristik sosial ekonomi masyarakat. Baik itu dilihat dari segi pendidikan formal, pendapatan, pengeluaran per bulan, atau akses informasi. Individuindividu inovatif relatif lebih elit dibandingkan dengan mereka yang menolak 
untuk menggunakan teknologi komunikasi baru. Alasan mendasar untuk penjelasan tersebut adalah media yang baru merepresentasikan biaya yang tidak kecil, dan masyarakat dengan tingkat status ekonomi sosial yang tinggi mempunyai kemampuan untuk membelinya dibandingkan dengan lainnya. Kemudian orang-orang yang berpendidikan mempunyai kesadaran yang lebih tinggi akan keutamaan manfaat teknologi komunikasi baru. Hubungan yang positif antara status sosial ekonomi dan keinovasian merupakan alasan mendasar mengapa teknologi komunikasi baru semakin memperlebar gap informasi dalam masyarakat antara informasi yang mahal dengan informasi yang murah.

\section{Hubungan antara Pendidikan dengan Pengambilan Keputusan Inovasi Siaran Televisi Digital}

Tingkat korelasi (hubungan) antara pendidikan dengan Pengambilan Keputusan Inovasi adalah lemah dan signifikan dengan nilai uji 0,398 signifikan pada alpha 0.05 (5\%). Artinya, aspek pendidikan hanya memberikan kontribusi sebesar 39,75\% terhadap Pengambilan Keputusan Inovasi siaran televisi digital. Dalam melihat hasil uji statistik ini, pertama dapat kembali dilihat data pendidikan responden, di mana pendidikan responden dengan kategori terbesar adalah pada kategori sedang dengan persentase $61,62 \%$, disusul dengan kategori pendidikan rendah pada persentase 13,04\%, dan kategori tinggi 25,34\%. Gambaran tingkat pendidikan responden tersebut, secara berarti memberikan kontribusi yang cukup besar terhadap tingkat adopsi yang muncul. Proporsi responden yang paling tinggi terhadap kesiapan membeli televisi digital baru bila dilihat dari aspek pendidikan, adalah pendidikan kategori tinggi (yaitu kelompok responden dengan tingkat pendidikan lulusan minimum sarjana strata satu/ S1). Sementara proporsi responden yang paling tinggi terhadap kesediaan membeli/ memasang peralatan tambahan (STB) pada televisi analog yang sudah dimiliki responden, adalah kelompok responden dengan pendidikan kategori sedang (yaitu lulusan SMA hingga Diploma). Dan proporsi responden selebihnya yang tidak ada kesanggupan apapun berada pada responden dengan kategori pendidikan rendah, yaitu lulusan SD dan SMP. Hal ini menunjukkan, secara tidak langsung, tingkat pendidikan seseorang sebenarnya dapat mengubah pola pikir, daya penalaran yang lebih baik, sehingga makin lama seseorang mengenyam pendidikan akan semakin rasional. Artinya individu yang berpendidikan tinggi adalah relatif lebih cepat dalam melaksanakan adopsi teknologi. Begitu pula sebaliknya, mereka yang berpendidikan rendah agak sulit untuk melaksanakan adopsi inovasi dengan cepat.

Dengan berdasarkan asumsi bahwa tingkat pendidikan sangat berpengaruh pada pengambilan keputusan terhadap suatu isu, maka semakin tinggi tingkat pendidikan masyarakat akan semakin terbuka terhadap berbagai isu yang muncul. Berdasarkan keterkaitannya antara pendidikan dan ekspektasi terhadap migrasi ke siaran televisi digital di masa depan, tampaknya masyarakat memberikan reaksi yang sangat positif.

\section{Hubungan antara Penghasilan dengan} Pengambilan Keputusan Inovasi terhadap Sistem Siaran Televisi Digital

Tingkat korelasi (hubungan) antara penghasilan perbulan dengan Pengambilan Keputusan Inovasi adalah lemah dan signifikan dengan nilai uji 0,342 signifikan pada alpha $0.05 \quad(5 \%)$. Artinya aspek penghasilan responden memberikan kontribusi sebesar $34,21 \%$ terhadap Pengambilan Keputusan Inovasi siaran televisi digital.

Kontribusi aspek penghasilan responden yang tidak begitu besar terhadap Pengambilan Keputusan Inovasi, sangat dipengaruhi oleh penghasilan responden yang menunjukkan, 69,99\% penghasilan responden berada pada kategori sedang, serta kategori rendah sebesar $28,74 \%$. Justru kategori penghasilan tinggi hanya sebesar 5,27\%. Migrasi sistem analog ke sistem digital, dari sisi pembiayaan cukup tinggi. Selain infrastrukturnya yang mahal, masyarakat 
yang ingin menikmati siaran televisi digital harus mengganti pesawat televisi mereka dengan televisi yang sudah menerapkan sistem digital atau built in digital, atau alternatif lebih murah adalah dengan membeli perangkat STB.

Kondisi tersebut menggambarkan bahwa untuk program migrasi televisi digital dapat memicu problem sosial terutama untuk kalangan yang memiliki pendapatan rendah, karena sekalipun untuk membeli STB, sudah merupakan beban ekonomi yang berat.

\section{Hubungan antara Pengeluaran dengan} Pengambilan Keputusan Inovasi terhadap Sistem Siaran Televisi Digital

Tingkat korelasi (hubungan) antara pengeluaran perbulan dengan Pengambilan Keputusan Inovasi adalah sangat lemah dan tidak signifikan dengan nilai uji 0,262 tetapi masih signifikan pada alpha 0.1 (10\%). Aspek pengeluaran responden memberikan kontribusi sebesar 26,2\% terhadap Pengambilan Keputusan Inovasi. Persentase tersebut jauh lebih rendah dibandingkan dengan aspek pendidikan ataupun penghasilan responden. Gambaran persentase pengeluaran responden tidak jauh berbeda dengan gambaran penghasilan responden, dengan kategori terbesar berada pada kategori sedang sebesar 66,17\%. Individu yang memiliki status yang lebih tinggi mempunyai kemungkinan yang lebih besar dalam menggunakan inovasi televisi digital tersebut karena hal tersebut dipandang sebagai simbol status sosial.

Hal tersebut menunjukkan bahwa potensi masyarakat untuk membeli alat tambahan (STB) atau pun mengganti televisinya menjadi digital rendah. Artinya, seandainya program migrasi televisi digital mengharuskan masyarakat untuk mengganti televisi yang sudah mereka miliki dengan televisi baru, maka dapat diprediksi akan dapat menimbulkan persoalan sosial besar. Akan tetapi, karena ada altematif lain dengan hanya membeli alat tambahan (STB) dengan harga sekitar Rp300.000, maka program ini diperkirakan tidak akan menimbulkan masalah apa pun. Apalagi cara pemasaran saat ini sudah sangat maju dan orang dapat bercermin pula dari kasus HP dalam masyarakat.

\section{Hubungan antara Akses Informasi dengan Pengambilan Keputusan Inovasi terhadap Sistem Siaran Televisi Digital}

Tingkat korelasi (hubungan) antara akses informasi dengan Pengambilan Keputusan Inovasi adalah sedang/cukup dan signifikan dengan nilai uji 0,509 signifikan pada alpha 0.05 (5\%). Kontribusi yang diberikan aspek akses informasi ini sebesar 50,91\%. Angka ini bila dibandingkan dengan ketiga indikator karakteristik sosial lainnya, adalah yang paling tinggi.

Kebutuhan informasi bagi pengadopsi adalah hal penting. Informasi akan memberikan dukungan kepada pengadopsi untuk mengantarkan mereka memasuki Pengambilan Keputusan Inovasi pertama yaitu knowledge stage. Jadi gambaran mengenai kecenderungan perilaku komunikasi dari individu yang lebih inovatif dalam menggunakan teknologi komunikasi baru adalah bahwa mereka merupakan para pencari informasi yang lebih aktif mengenai informasi semacam itu.

Saluran komunikasi adalah alat atau sarana di mana pesan didapatkan dari satu inidividu ke inidividu lain. Saluran-saluran media massa dipandang lebih efektif dalam menciptakan pengetahuan inovasi, sedangkan saluran interpersonal lebih efektif dalam membentuk dan mengubah sikap terhadap suatu ide, dan sehingga secara langsung memengaruhi keputusan untuk mengadopsi atau menolak ide baru.

Mereka mencari informasi tidak terbatas pada media massa, tetapi dari lingkungan pergaulan mereka, para ahli, serta melalui berbagai bacaan. Bahkan hasil penelitian menunjukkan, jaringan interpersonal memiliki posisi yang cukup penting dibandingkan dengan media massa dalam menyebar pengetahuan tentang televisi digital. Lebih dari setengah responden mengatakan mereka pertama kali mendengar tentang televisi digital dari sumber interpersonal seperti teman sejawat, teman 
bergaul, dan anggota keluarga. "Kebanyakan penelitian sebelumnya melaporkan bahwa media massa adalah hal penting yang telah membangun pengetahuan tentang inovasi, terutama sekali pada tahap awal proses difusi“ (Rogers, 1986). Namun proses jaringan interpersonal ternyata memiliki posisi penting.

Tidak setiap teknologi baru masuk dengan mudah ke dalam masyarakat. Adopsi inovasi akan berjalan secara bertahap. Ketika komputer atau telepon genggam mulai diperkenalkan kepada masyarakat, tidak serta merta masyarakat bisa mengadopsi teknologi tersebut dengan cepat. Tetapi melalui suatu proses yang bisa dikatakan cukup panjang. Terlebih tidak banyak anggota masyarakat yang dapat menyesuaikan kebiasaan terdahulu mereka menggunakan perangkat dengan fungsi yang sama untuk kemudian beralih menuju perangkat yang canggih.

\section{PENUTUP}

\section{Simpulan}

Absorpsi masyarakat dalam menghadapi migrasi siaran televisi analog ke siaran televisi digital dapat dideskripsikan sebagai kemampuan (daya tahan) masyarakat dalam mempersiapkan diri untuk memasuki proses adopsi inovasi teknologi. Komponen instrumen untuk mengukur kapasitas absorpsi masyarakat dengan 3 (tiga) aspek adalah: Pendidikan, kemampuan ekonomi masyarakat yang dilihat dari pendapatan, dan pengeluaran, dan akses informasi.

Karakteristik sosial ekonomi responden, menunjukkan, berada pada kategori sedang.

Tahap pengetahuan responden tentang sistem siaran televisi digital berada pada proporsi kategori rendah. Meskipun demikian, responden sebagian besar menyambut baik terhadap kehadiran sistem siaran televisi digital ini. Komposisi ini bisa menjelaskan, bahwa program migrasi ke televisi digital belum ada gaungnya di masyarakat.

Sebagian besar aspek tahap persuasi memiliki persentase yang relatif sedang- tinggi. Hal ini menunjukkan adanya hubungan positif aspek-aspek inovasi dengan kecepatan adopsinya yang dijelaskan oleh lima aspek (keunggulan relatif, kesesuaian, kerumitan, ketercobaan, dan keteramatan) dengan relatif pada kategori sedang-tinggi.

Responden pada umumnya merasa senang sekali terhadap kehadiran program penyiaran televisi digital, dan sebagian kecil saja yang menyatakan biasa saja. Sebaliknya yang merasa tidak senang juga cukup besar, umumnya mereka tidak siap secara ekonomi. Komposisi ini memperlihatkan ekspektasi yang tinggi terhadap adanya program migrasi ke televisi digital.

Pengambilan Keputusan Inovasi terhadap sistem siaran televisi digital dalam tiga kategori memperlihatkan kecenderungan sedang-tinggi.

Hubungan antara variabel karakteristik soasial ekonomi dengan Pengambilan Keputusan Inovasi pada empat aspek, yaitu pendidikan, pendapatan, dan pengeluaran yang lemah, serta aspek akses informasi dengan nilai hubungan yang tinggi mengisyaratkan akan perlunya upaya untuk penguatan kapasitas absorpsi masyarakat dapat dilakukan dengan memperbaiki nilai setiap komponen yang ada pada tataran operasional yaitu di antaranya sebagai prioritas adalah bagaimana upaya untuk meningkatkan kemampuan ekonomi masyarakat khususnya dari sisi pendidikan, penghasilan, dan pengeluaran per bulan.

Asumsi yang mengatakan bahwa tingkat pendidikan sangat berpengaruh pada pengambilan keputusan terhadap tingkat adopsi inovasi, maka semakin tinggi tingkat pendidikan masyarakat akan semakin terbuka terhadap berbagai inovasi yang muncul.

Reaksi yang cukup positif dari responden terhadap migrasi siaran televisi analog ke siaran televisi digital dapat dideskripsikan sebagai prediksi ke depan mengenai ekspektasi masyarakat terhadap difusi inovasi teknologi baru. Dalam hal ini berkaitan dengan upaya pemerintah untuk rnengimplementasikan teknologi penyiaran televisi digital. 


\section{Saran}

Perlunya ada program dari Kementerian Komunikasi dan Informatika yang mempersiapkan masyarakat sebagai users baik itu berupa program sosialisasi atau apapun namanya dengan demikian diharapkan tingkat partisipasi masyarakat akan semakin tinggi, karena sudah dipersiapkan. Hal ini juga sebagai upaya yang dapat mengurangi resistensi penerimaan migrasi televisi digital, selain juga dapat meningkatkan ekspektasi masyarakat.

Fakta di lapangan, sebagian masyarakat Indonesia masih berada pada tingkat pendapatan yang masih rendah dengan daya beli yang rendah pula. Kondisi ini perlu ditanggapi dengan cermat dengan suatu langkah yang memungkinkan dapat mengurangi beban ekonomi mereka ketika menerima migrasi televisi digital ini dilaksanakan.

\section{DAFTAR PUSTAKA}

\section{Buku:}

Rogers, Everett M. (1986). Communication Technology. The New Media in Society. New York: Free Press

Rogers, Everett M. (1995). Diffusion of Innovation. New York: Free Press

Rogers, Everett M., and Shoemaker. (1971). Communication of Innovations. New York: Free Press

Severin, Werner J dan James W. Tankard. (2005). Teori Komunikasi. Jakarta: Kencana.

Surakhmad, Winarno. (1994). Pengantar Penelitian Ilmiah dan Dasar Metode Teknik. Bandung: Transito.

\section{Sumber lainnya: \\ Jurnal:}

Yusuf, Iwan Awaluddin. (2012). Problematika Infrastruktur dan Teknologi dalam Transisi dari Sistem Penyiaran Analog Menuju Digital. IPTEK-KOM, Vol. 14, No. 2, Desember hal. 177-190.

\section{Laporan Penelitian/Artikel Seminar:}

PIH Kominfo. (2012). Konvergensi, Edisi III Tahun 2012. Jakarta: Kominfo.

Subiantoro, Bambang. (2010). Prospek Bisnis Penyiaran di Indonesia yang Dipengaruhi Kemajuan Teknologi. Naskah dipresentasikan dalam Rakornas KADIN, Jakarta.

Soemarsono, dkk. (2010). Studi Kesiapan Masyarakat terhadap Penerapan Sistem Penyiaran Televisi Berteknologi Digital di Indonesia. Badan Litbang SDM Kementerian Kominfo

\section{Regulasi:}

Peraturan Menteri Kominfo No.22/PER/M.KOMINFO/11/2011 tentang Penyelenggaraan Penyiaran Televisi Digital Teresterial Penerimaan Tetap Tidak Berbayar (Free To Air).

Peraturan Menteri Kominfo No.23/PER/M.KOMINFO/11/2011 tentang Rencana Induk (Masterplan) Frekuensi Radio Untuk Keperluan Televisi Siaran Digital Teresterial.

Peraturan Menteri No. 07/P/M.KOMINFO/3/2007 tentang Standar Penyiaran Digital Terrestrial untuk Televisi Tidak Bergerak.

\section{Internet:}

Wibawa, Arif dkk. (2011). Model Bisnis Penyiaran Televisi Digital di Indonesia Prodi Ilmu Komunikasi, FISIP UPN "Veteran" Yogyakarta. Tersedia dalam $<$ http://lib.atmajaya.ac.id/default.aspx? tabID $=61 \&$ src $=$ a\&id $=264928>$. Diakses tanggal 29 Agustus 2013.

Ditjen SDPPI. (2008). Selamat Datang Era Penyiaran televisi dan Radio Digital. Siaran Pers No. 55/DJPT.1/KOMINFO/5/2008. 12-052008. Tersedia dalam $<$ http://www.postel.go.id/info_view_c 26 p_713.htm $>$. Diakses tanggal $2 \overline{8}$ Agustus 2013.

Hafni, Zunita. (2011). Pengaruh 
Karakteristik Inovasi dan Sistem Sosial terhadap Adopsi Inovasi Program Bina Keluarga Balita (BKB) di Kelurahan Kwala Bingai Kecamatan Stabat Kabupaten Langkat. Master Theses, University of Sumatera Utara (USU). Tersedia dalam

$<$ http://repository.usu.ac.id/handle/123 456789/30598>. Diakses tanggal 28 Agustus 2013.

Sindonews.com. (2013). Indonesia memasuki era televisi Digital. Advertorial. Tersedia dalam $<$ http://ekbis.sindonews.com/read/201 3/07/25/34/765040/indonesiamemasuki-era-televisi-digital $>$ atau di
$<$ http://televisidigital.kominfo.go.id/? $\mathrm{p}=130>$. Diakses tanggal 4 September 2013.

Subarkah, AW. (2009). Sejarah televisi Digital Baru Dimulai. Tersedia dalam $<$ http://tekno.kompas.com/read/2009/0 7/16/04404267/sejarah.televisi.digital. baru.dimulai>. Diakses tanggal 28 Agustus 2013.

Ucapan terimakasih peneliti sampaikan kepada tim pelaksana pengumpulan data penelitian di 7 (tujuh) lokasi Kabupaten/Kota di Provinsi Jawa Barat dan Banten. 